Nikola N. Gavrilović

Graduate Research Assistant University of Belgrade

Faculty of Mechanical Engineering

Boško P. Rašuo

Full Professor

University of Belgrade

Faculty of Mechanical Engineering

George S. Dulikravich

Full Professor

Florida International University Department of Mechanical and Materials Engineering, Miami, Florida, USA

Vladimir B. Parezanović

Researcher Institute PPRIME, CNRS UPR3346

Poitiers,

France

\section{Commercial Aircraft Performance Improvement Using Winglets}

Aerodynamic drag force breakdown of a typical transport aircraft shows that lift-induced drag can amount to as much as $40 \%$ of total drag at cruise conditions and $80-90 \%$ of the total drag in take-off configuration. One way of reducing lift-induced drag is by using wing-tip devices. By applying several types of winglets, which are already used on commercial airplanes, we study their influence on aircraft performance. Numerical investigation of five configurations of winglets is described and preliminary indications of their aerodynamic performance are provided. Moreover, using advanced multi-objective design optimization software an optimal one-parameter winglet configuration was determined that simultaneously minimizes drag and maximizes lift

Keywords: Winglet, Bionics, Computational fluid dynamics, Drag reduction, Lift-induced drag, Optimization.

\section{INTRODUCTION}

The main motivation for using wingtip devices is reduction of lift-induced drag force. Environmental issues and rising operational costs have forced industry to improve the efficiency of commercial air transport and this has led to some innovative developments for reducing lift-induced drag. Several different types of wingtip devices have been developed during this quest for efficiency and the selection of wingtip device depends on the specific situation and airplane type. Commercial passenger aircrafts spend most of their operational life at cruise condition, thus all wingtip shapes need to be examined in those conditions in order to justify their purpose.

Winglets allow for significant improvements in the aircraft fuel efficiency, range, stability, and even control and handling [1]. They are traditionally considered to be near-vertical, wing-like surfaces that can extend both above and below the wing tip where they are placed. Some designs have demonstrated impressive results, like 7 percent gains in lift-to-drag ratio and a 20 percent reduction in drag due to lift at cruise conditions [2].

The concept of winglets was originally developed in the late 1800 s by British aerodynamicist Frederick W. Lanchester, who patented an idea that a vertical surface (end plate) at the wingtip would reduce drag by controlling wingtip vortices [3]. Unfortunately the concept never demonstrated its effectiveness in practice because the increase in drag due to skin friction and flow separation outweighed any lift-induced drag benefit. Long after Frederick W. Lanchester, engineers at NASA Langley Research Centre inspired by an article in Science Magazine on the flight characteristics of soaring birds and their use of tip feathers to control flight, continued on the quest to reduce induced drag and improve aircraft performance and further develop

Received: May 2014, Accepted: July 2014

Correspondence to: Boško Rašuo

Faculty of Mechanical Engineering,

Kraljice Marije 16, 11120 Belgrade 35, Serbia

E-mail: brasuo@mas.bg.ac.rs

doi:10.5937/fmet1501001G

(C) Faculty of Mechanical Engineering, Belgrade. All rights reserved the concept of winglets in the late 1970s [4]. This research provided a fundamental knowledge and design approach required for extremely attractive option to improve aerodynamic efficiency of civilian aircraft, reducing their fuel consumption and increasing operating range.

\section{LIFT AND DRAG OF FINITE SPAN WINGS}

Finite span wings generate lift due to pressure imbalance between the bottom surface (high pressure) and the top surface (low pressure). The higher pressure air under the wing flows around the wingtips and tries to displace the lower pressure air on the top of the wing. The flow around a wingtip is sketched in Fig. 1. These phenomena are referred to as wingtip vortices with high velocities and low pressure at their cores. These vortices induce a downward flow known as the downwash. This downwash has the effect of tilting the free-stream velocity to produce a local relative downward wind, which reduces the angle of attack that the wing experiences. Moreover, it creates a component of drag, the lift-induced drag, as presented in [5].

Equation of the total drag of a wing is a sum of the parasite drag and the induced drag. In terms of nondimensional coefficient of drag it is [5]:

$$
C_{D}=C_{D 0}+C_{\text {Dind }}
$$

Here, $C_{D 0}$ is the drag coefficient at zero lift and is known as the parasite drag coefficient, which is independent of the lift. The second term on the righthand side of Eq. (1) is the lift-induced drag coefficient, $C_{\text {Dind }}$, defined as:

$$
C_{\text {Dind }}=\frac{C_{L}^{2}}{\pi \lambda e}
$$

In Eq. (2), $C_{L}$ is the wing lift coefficient, $\lambda$ is the wing aspect ratio and $\mathrm{e}$ is Oswald efficiency factor (which is a correction factor that accounts for the difference between the actual wing and an ideal wing having the same aspect ratio and elliptical lift distribution) or wingspan efficiency. 


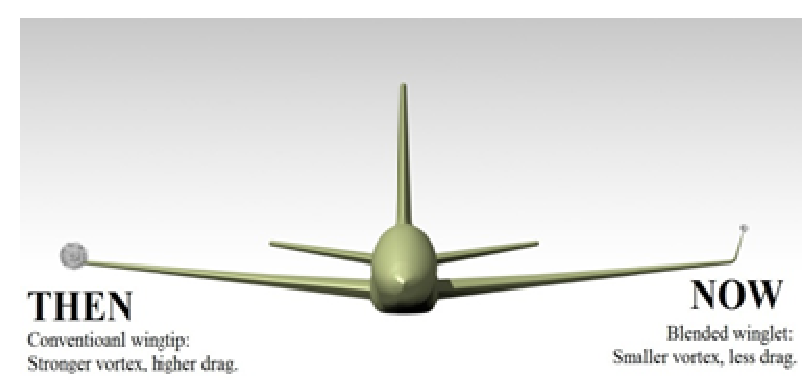

Figure 1. Wingtip vortex

\section{CFD ANALYSIS}

The computational effort performed in this research consisted of three stages. The work began from preprocessing stage of geometry setup and grid generation. The geometry of the passenger aircraft model was drawn using CATIA V5 R21 [6]. Geometry setup was made using surface design in order to draw 3D model as shown in Fig 2. Computational grid was generated by Auto Mesh program in ANSYS. The second stage was CFD simulation by FLUENT software using finite volume approach. Finally, the post-processing stage was used where the aerodynamic characteristics of the wing were defined [7].

\subsection{Geometry}

As a representative aircraft geometry, a typical mediumsize commercial aircraft was chosen because such aircraft performs a large number of flights per year, thus fuel consumption is of great importance. The wingspan of the representative aircraft was $38 \mathrm{~m}$. Tail height, length and wing area were $13.5 \mathrm{~m}, 47 \mathrm{~m}$ and $194 \mathrm{~m}^{2}$, respectively. The airfoil chosen for the root of the wing was NACA $64_{1}-412$, while the wingtip airfoil was NACA $65-410$.

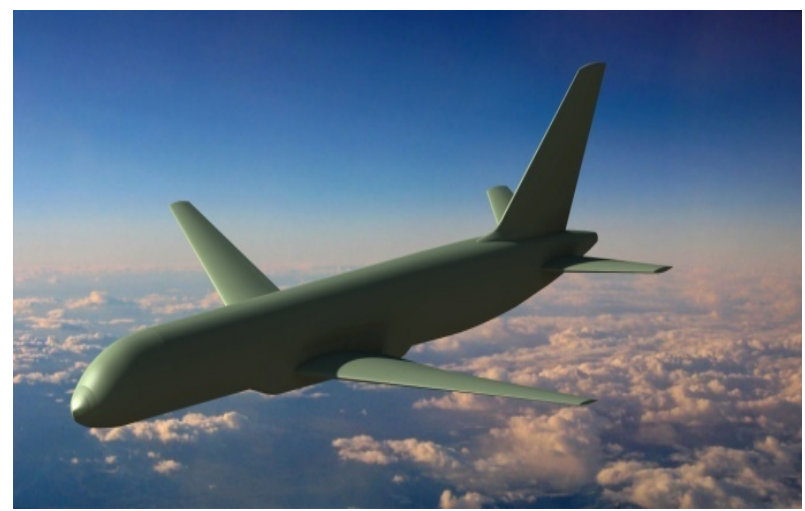

Figure 2. Airplane model geometry

The value of maximum takeoff weight affecting the choice of wing airfoils was $115,000 \mathrm{~kg}$. Control surfaces of the aircraft had symmetric airfoils. The figure above shows the geometry designed in CATIA software.

A blended winglet was attached to the wing tip with a smooth curve instead of a sharp angle which was intended to reduce interference drag at the wing/winglet junction. A sharp interior angle in this region can interact with the boundary layer flow causing a drag inducing vortex, negating some of the benefits of the winglet. Such blended winglets are used on business jets and sailplanes, where individual buyer preference is an important marketing aspect [1]. Blended winglet used in this work is shown in Fig 3.

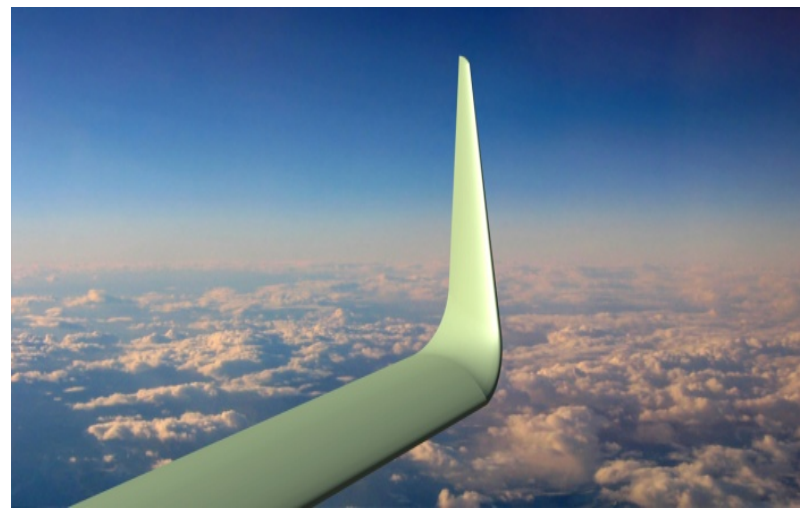

Figure 3. Blended winglet

A wingtip fence refers to the winglets used in some Airbus airplane models which include surfaces extending above and below the wing tip. Both surfaces are shorter than or equivalent to a winglet possessing similar aerodynamic benefits. Wingtip fences were the preferred wingtip device of Airbus for many years [4]. Wingtip fence modelled in CATIA is shown in Fig 4.

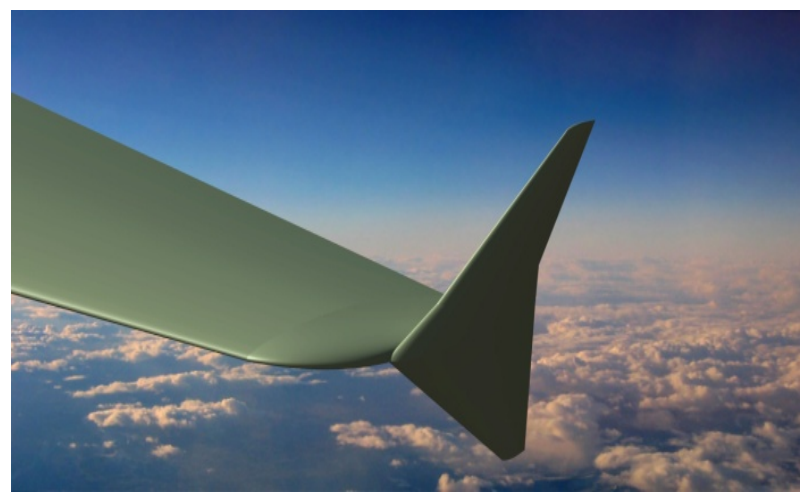

Figure 4. Wingtip fence

The Boeing 737 MAX uses a new type of wingtip device. Resembling a three-way hybrid between a blended winglet, wingtip fence, and raked wingtip, Boeing claims that this new design should deliver an additional $1.5 \%$ improvement in fuel economy over the $10-12 \%$ improvement already expected from the 737 MAX [8]. A similar shape was analyzed in the present study as shown in Fig 5 and was recently optimized [9].

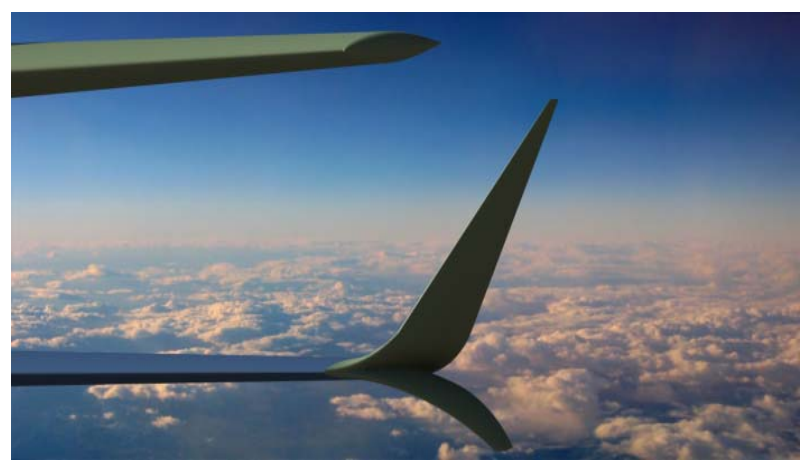

Figure 5. MAX winglet concept 
Another interesting shapes could be designed by looking at analogous shapes in nature. Birds wingtip feathers with their large variety in morphology are biological examples to examine. In Fig. 6, it can be seen how the wingtip feathers of an eagle are bent up and separated (like the fingers of a spreading hand). This wingtip feathers slotted configuration is thought to reduce the lift-induced drag caused by wingtip vortices.

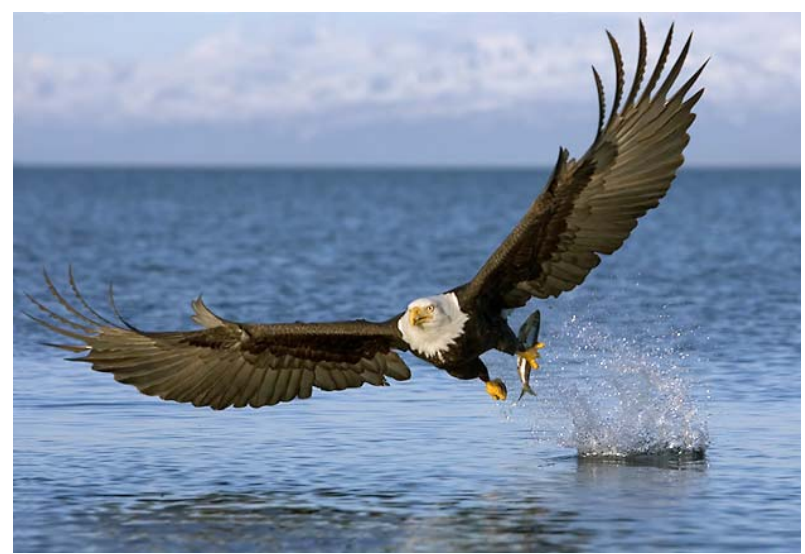

Figure 6. Eagle's wingtip feathers

This implementation by bionic abstraction can be improved even further and aesthetically adapted to wings by designing a spiral loop that externally wraps the wing tip extension (see Fig. 7.) [10].

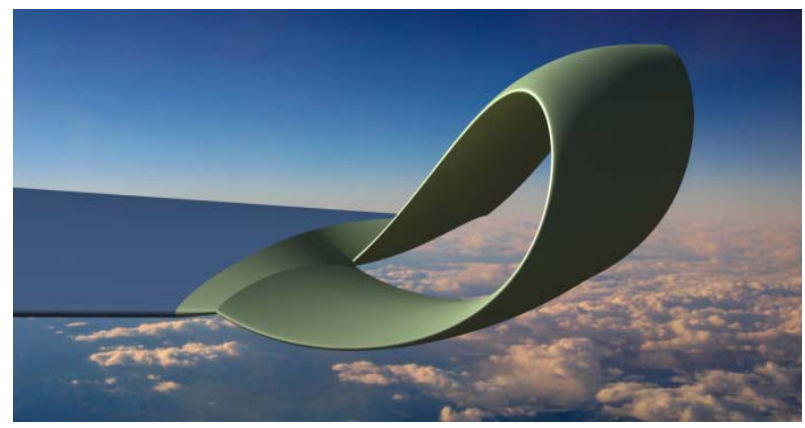

Figure 7. Spiroid winglet 1

However, for a variety of reasons, it is understood that identical copies from nature to man-made technologies are not feasible in bionics. Instead, bionics encompasses a creative conversion into technology that is often based on various steps of abstractions and modifications, that is, an independent successive construction that is rather a "new invention" [10] than a blueprint of nature. The following figure shows the form that was created after spiroid model, in order to develop a technologically more feasible solution.

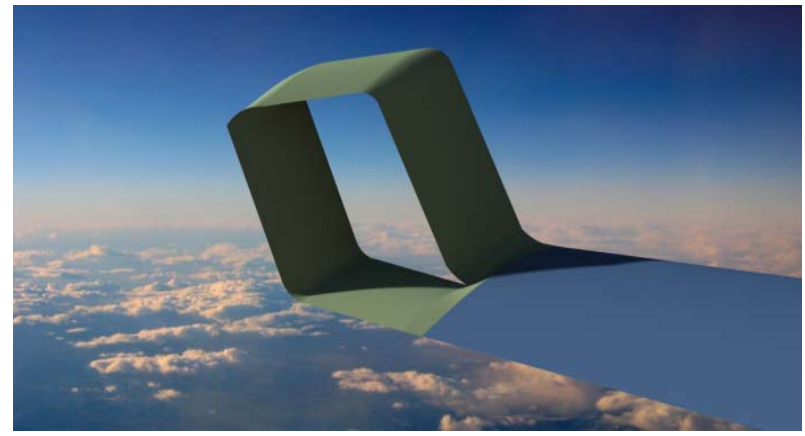

Figure 8. Spiroid winglet 2

\subsection{Computational grid}

Unstructured tetrahedral grid was utilized for computing the flow-field around the 3D configurations. Unstructured grid is appropriate due to the complexity of the model. A typical mesh is made-up of approximately 8 million elements. After the gridding process, the grid was examined to check its quality by observing the skewness level and abrupt changes in grid cell sizes [11].



Figure 9. The computational grid on surfaces of models

\subsection{Numerical simulation}

The numerical simulation by FLUENT solver was performed after the completion of the grid generation and simulated 3D compressible turbulent flow using Navier-Stokes equations. Turbulence model was the realizable $\mathrm{k}-\varepsilon$ with appropriate solid wall boundary condition. Solver control parameters and fluid properties were also defined at this stage.

FLUENT software provides the user with seven turbulence models [7]. Lower order turbulence models tend to be less accurate than higher order ones. SpalartAllmaras model is a low Reynolds number one-equation turbulence model that solves for the kinematic eddy viscosity, which means that Spalart-Allmaras is lightweight among available turbulence models. The last four turbulence models are skipped because they require far too much computing power. So, the only options that are left are-two equation turbulence models, the $\mathrm{k}-\varepsilon$ and $\mathrm{k}-\omega$ model. Since its introduction, $\mathrm{k}-\varepsilon$ model has become the most widely used turbulence model. The key advantages of $\mathrm{k}-\varepsilon$ model are its economy, reasonable accuracy and its applicability to wide range of flow types. The realizable $\mathrm{k}-\varepsilon$ model is the best option when dealing with flow containing high pressure gradients and separation [12].

After all the parameters were specified, the model was initialized. The initializing and iteration processes stopped after the completion of the computations [13]. Computations are carried out on one quad-core processor $3.2 \mathrm{GHz}$, with $16 \mathrm{~GB}$ of RAM, and each case took approximately 12 hours to converge. 


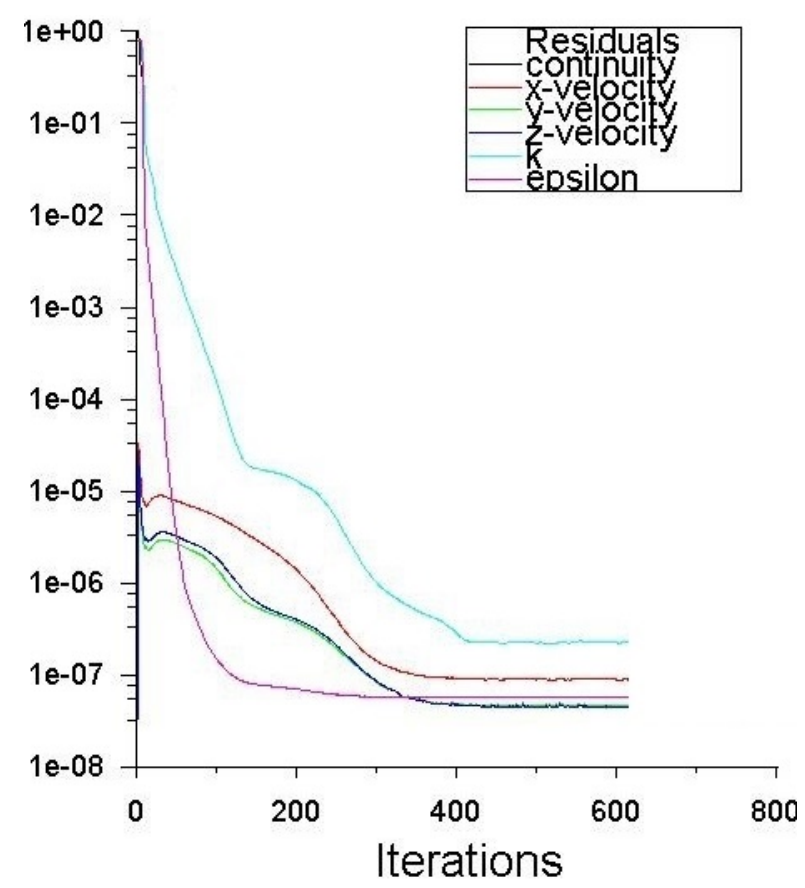

Figure 10. A typical convergence history of Fluent aerodynamic analysis

The results obtained were examined and analyzed.

\section{RESULT AND DISCUSSION}

The result from the 3D wing with winglet model was compared to the 3D wing without winglet. The discussions were focused on the aerodynamic characteristics which include drag coefficient, $C_{D}$, lift coefficient, $C_{L}$, and lift-to-drag ratio, $L / D$. In addition, the pressure coefficient contours and path lines will also be observed and studied. The simulation was carried out at various angles of attack, $\alpha$, and Mach number 0.8 .

\subsection{Pressure field behind wing}

Calculated pressure field in a plane perpendicular to the free stream and located three wing tip chord lengths downstream of the wingtip without and with winglets is displayed in Fig. 11. One can observe the intensity and location of the wing tip vortex. It can be seen in the following figures that vortex causes lower pressure in area where it formed, which implies high local velocities.

As illustrated in Fig. 11, wing without winglet forms a stronger vortex, which causes larger induced velocity and produces more drag, compared with any of other wings equipped with a winglet.

\subsection{Aerodynamic characteristics}

By varying the angle of attack of the wing, different values of the coefficient of lift and drag are obtained. These analyses revealed a difference of lift and drag coefficients for different types of wing tips. Figures 12 and 13 show the lift and drag curves for clean wing and a wing with different winglets.

With increase of angle of attack, lift and drag both grow. With increasing lift, rises the strength of the wing tip vortices and thus induced drag of the airplane.

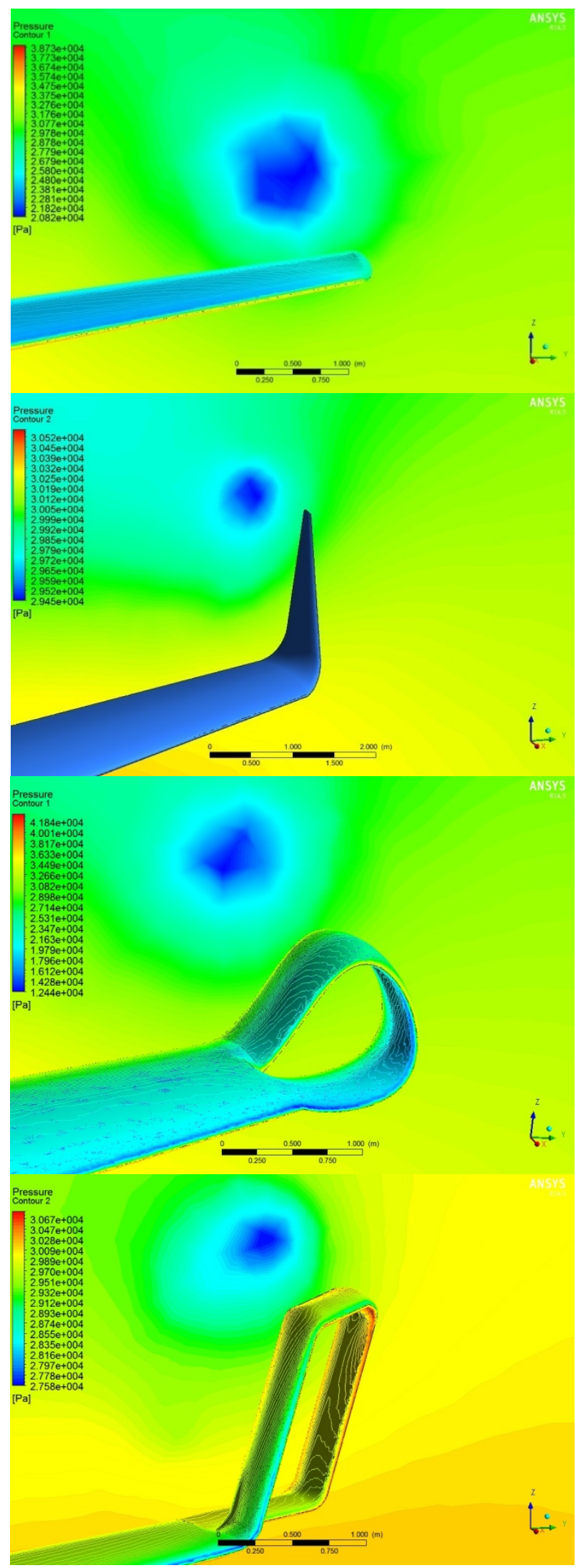

Figure 11. Pressure field behind wing with different winglet

By using a winglet, we reduce the strength of these vortices and thus induced drag. This performance improvement can be very important for the performance during takeoff and landing where this leads to shorter required runway length. By using these aerodynamic structures the climb performance is also improved by achieving higher speed of climbing. 


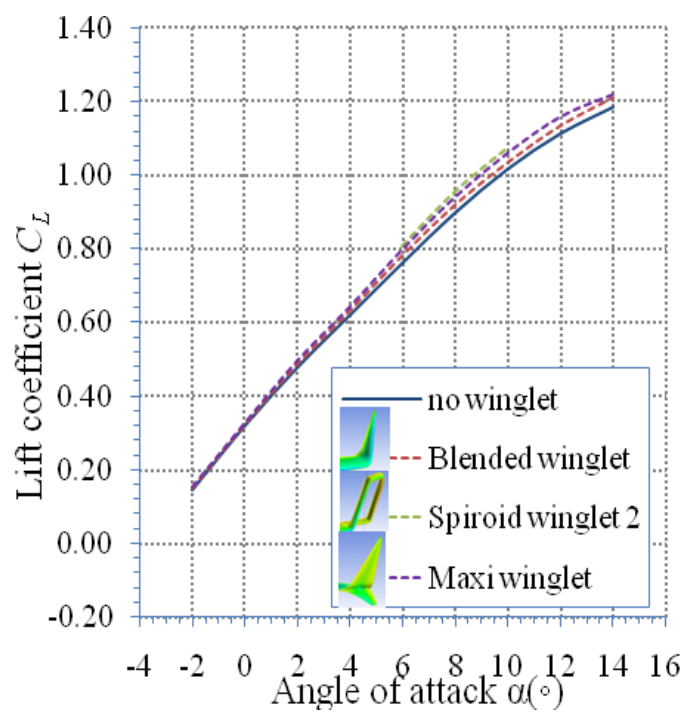

Figure 12. Lift curve

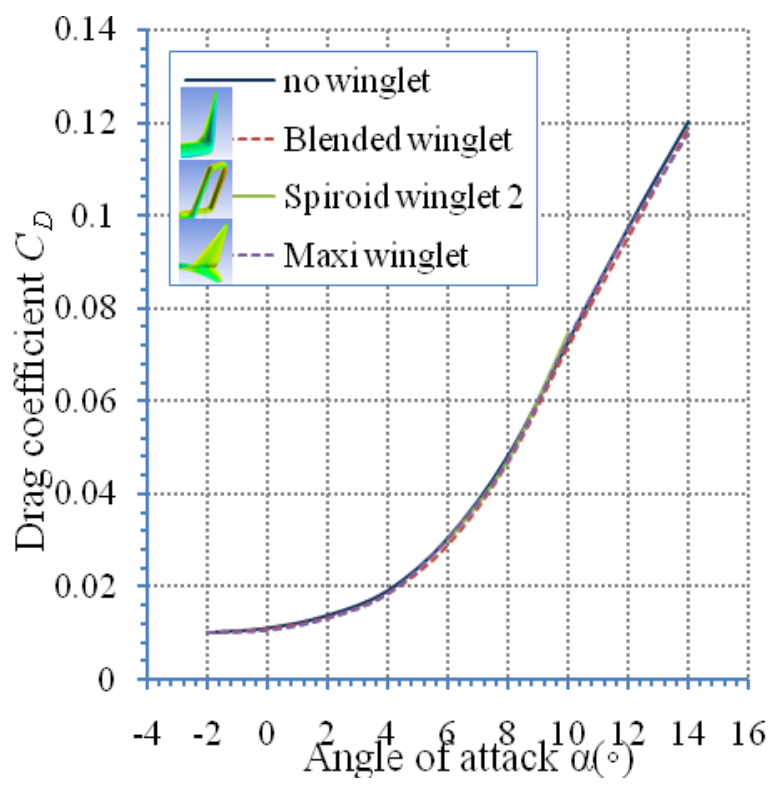

Figure 13. Drag curve



Figure 14. Aerodynamic polar curve

\subsection{Range analysis}

Improving performance in cruise flight regime is essential in increasing the value range of an airplane equiped with different winglets in comparison with a clean wing. With reducing drag and increasing lift, range L is significantly increased (Eq. 3). All values in Eq. (3) are defined for cruise mode [14].

$$
L_{\alpha H}=\frac{72}{c} \frac{C_{L}^{0,5}}{C_{D}} \sqrt{\frac{2\left(\frac{m_{1}}{s}\right)}{\rho g}}(1-\sqrt{1-\zeta})
$$

In Eq. (3), $c$ is specific fuel consumption, $C_{L}{ }^{0.5} / C_{D}$ is factor of range, $m_{l}$ is mass of empty aircraft, $s$ is wing area, $\rho$ is air density, $g$ is acceleration of gravity and $\zeta$ is the ratio between the mass of the fuel and the mass of empty aircraft.

Resulting ranges obtained with different winglets are given in Table 1 and Fig. 15 suggesting that spiroid winglets offered the least amount of improvements.

Table 1. Range for different wingtip shapes at cruise mode

\begin{tabular}{|c|c|c|c|}
\hline \multicolumn{4}{|c|}{ Cruise mode $(\mathrm{M}=0.8)$} \\
\hline Type of wingtip & ${\mathrm{C}_{\mathrm{L}}{ }^{0.5} / \mathrm{C}_{\mathrm{D}}} L[\mathrm{~km}]$ & $\%$ improv. \\
\hline No winglet & 37.39 & 7790.3 & \\
\hline Blended & 38.86 & 8096.6 & 3.78 \\
\hline Wing fence & 39.07 & 8140.4 & 4.30 \\
\hline Spiroid & 38.77 & 8077.9 & 3.56 \\
\hline Maxi & 39.38 & 8205.0 & 5.05 \\
\hline Spiroid 2 & 38.31 & 7982.0 & 2.40 \\
\hline
\end{tabular}

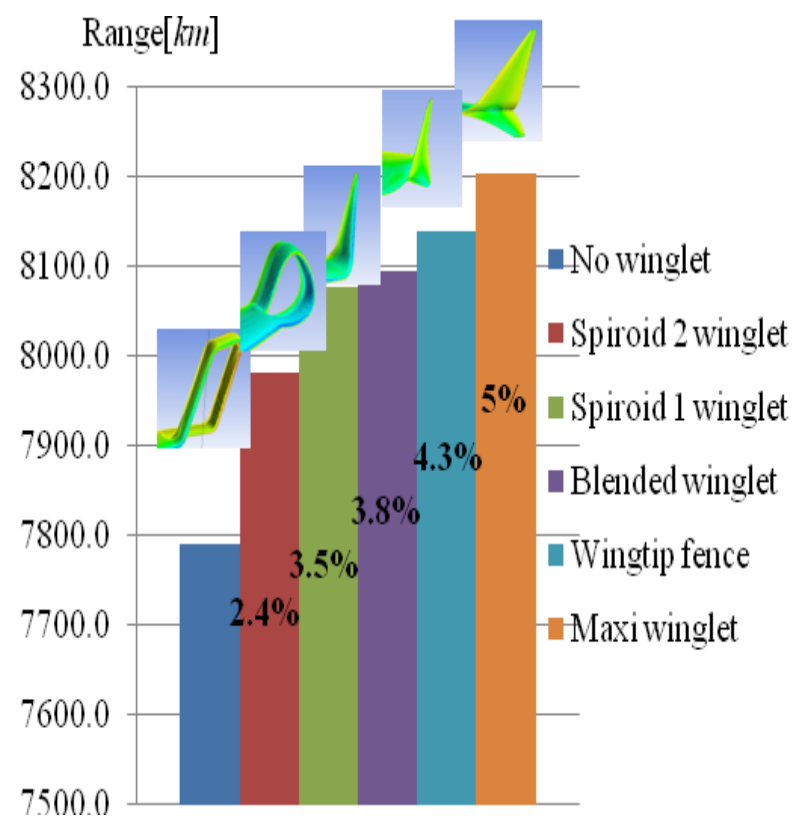

Figure 15. Range improvements over clean wing

Factor that directly affects range of the aircraft is relation $\mathrm{C}_{\mathrm{L}}^{0.5} / \mathrm{C}_{\mathrm{D}}$ which is presented in Fig. 16 for different winglets. It is also interesting to notice that the trade-off at maximum value of range factor is nearly $7.1 \%$ improvement which not only affects the range, but also fuel consumption as will be shown. The reason why 
spiroid winglets demonstrated poorest performance is because of their increased wetted surface and thus larger parasite drag. Also, interference is at much higher levels when using those shapes at wing tips as shown in [15].

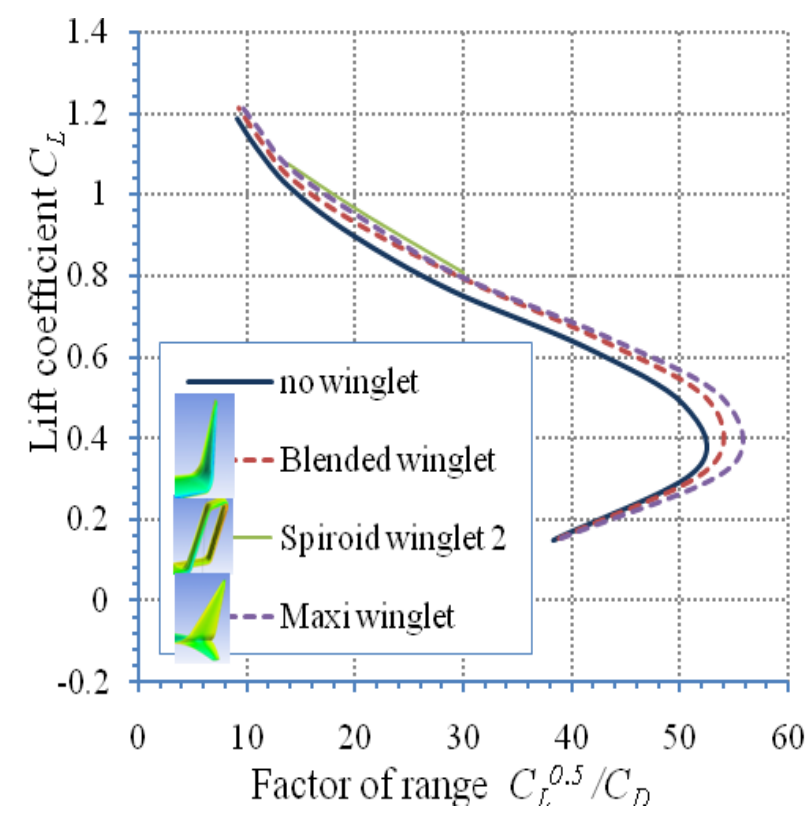

Figure 16. Factor of range

\subsection{Fuel consumption}

We have shown the effects of winglet shapes on aerodynamic coefficents. Now, we will present how they affect the fuel consumption. It is assumed that the plane flies 200 routes of up to 4000 kilometers per year. Figure 17 shows the amount of fuel consumed for 30 years of use. It can be seen from Fig. 16 that the amount of fuel saved can reach from 6000 tones up to 8000 tones, depending on a chosen winglet.

Figure 18 shows the number of passangers carried with the same amount of fuel for one year of usage, calculated in [15]. By using winglets, the amount of passangers carried increased significantly for the same amount of fuel.

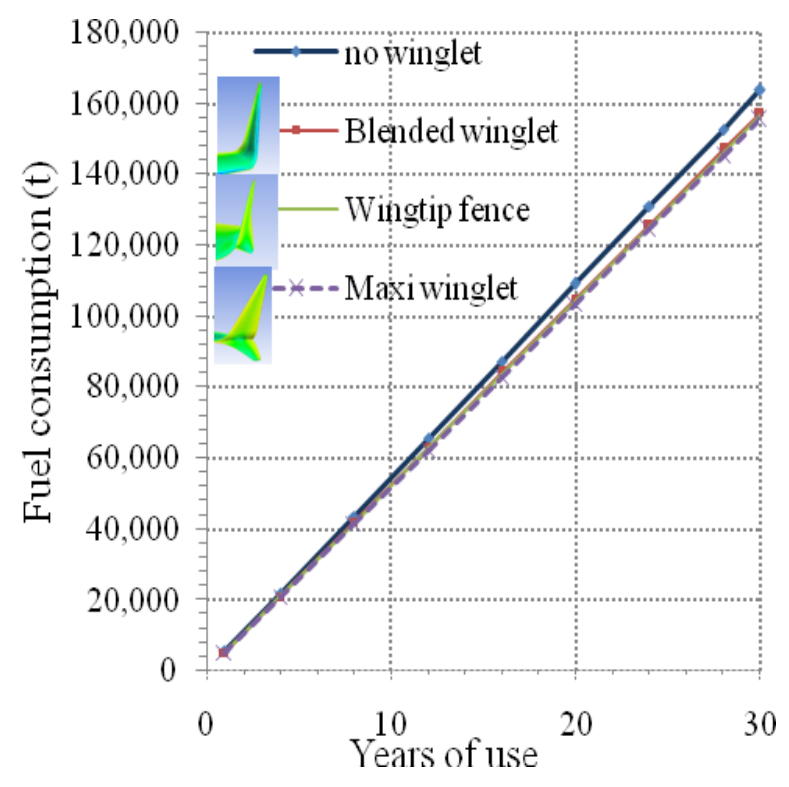

Figure 17. Fuel consumption

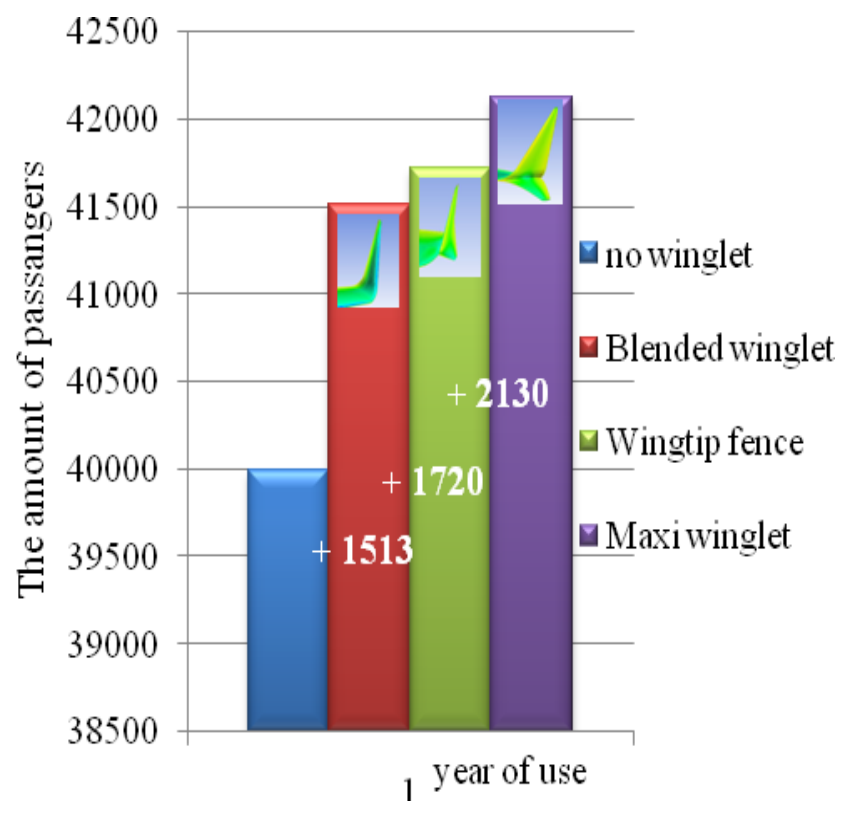

Figure 18. Number of passangers carried using equal amount of fuel

\section{OPTIMIZATION}

To answer the question of what is the best aerodynamic shape of the winglet, it is necessary to perform optimization for each of the previous analyzed winglets, with the aim to obtain such a shape that gives the best performance of the aircraft.

Approximately 100 winglet shapes were analyzed by varying the geometric parameters. Unfortunately, due to limited computer resources, we were forced to use only one parameter which describes the height and angle of the winglet. This parameter represents the position of profile that is connected with wing tip. Each configuration was analyzed using ANSYS Fluent software with free stream Mach number 0.8 . Geometry of the clean wing was the same in all of these analyses. The boundary conditions were defined in the same way as in the earlier calculations.

Response surfaces were then created with these 100 results. Non-Dominated Sorting Genetic Algorithm NSGA II in modeFRONTIER optimization software was then used to search the response surfaces for the Pareto optimal solutions of lift and drag (Fig. 19). Maximazing coefficient of lift and factor of range, while minimazing coefficients of drag were three simultaneous objectives.

Figure 19 shows the result of optimization where each point represents a unique shape of the winglet. It is interesting to notice that winglet shapes that extend from upper side of the wing tip give higher lift and drag coefficient. On the other hand winglet shapes that extend from lower side of the wing tip give lower lift and drag coefficients which confirms the validity of earlier findings [9]. From a wide range of shapes analyzed, the goal is to select the one giving the best aerodynamic characteristics. The value of factor of range was chosen in this study as an indicator that defines the most efficient form of wing tip. Fig. 20 shows the value of factor of range for every shape analyzed. 


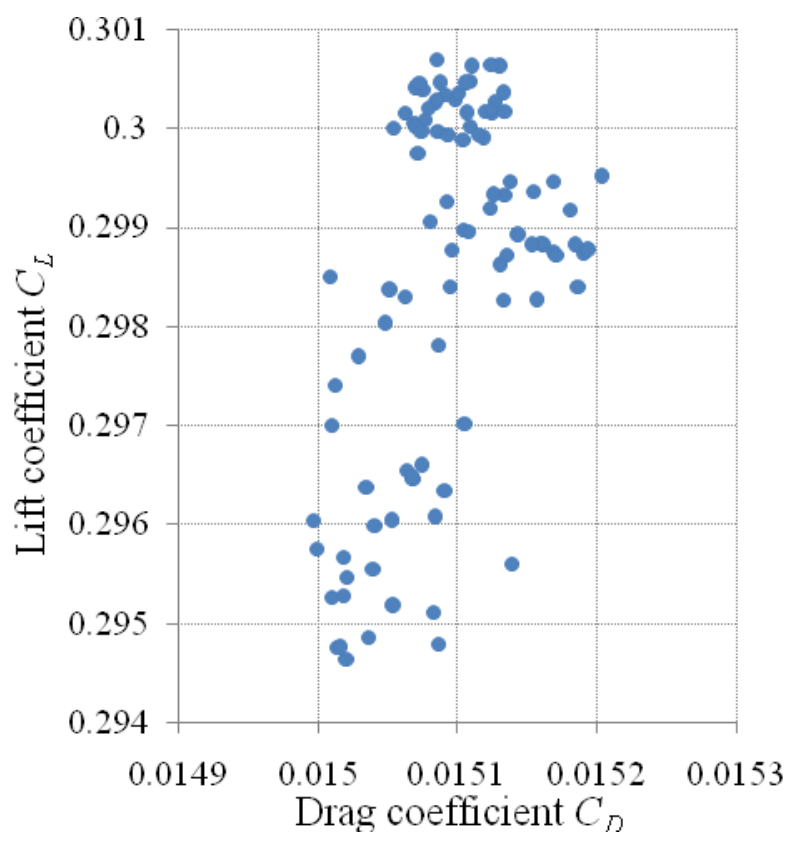

Figure 19. Optimization result for lift and drag at fixed $\alpha$



Figure 20. Factor of range for various winglet shapes

The Fig. 21 shows the shape with the highest value of factor of range (colored in red in Fig. 20). It should be pointed out that, when using a parallel computer with sizeable number of processors and relatively large memory it is possible to optimize smoothly curving winglets [9] and more complex scimitar winglets [16].



Figure 21. The most efficient winglet shape obtained

\section{CONCLUSION}

The classical way of reducing induced-drag is to increase the aspect ratio of the wing. However, wing aspect ratio is a compromise of weight, structural load and operational constraints. The alternative solution is the use of aerodynamic structures at the end of the wing, which reduces the strength of the vortices, thus reducing the lift-induced drag.

In this research, we have tested several wingtip shapes by adapting them to a clean wing. The performance of the wing with specific winglet relative to a clean wing has been studied quantitatively and qualitatively, and the following advantages and disadvantages were found.

Benefits:

- Improved generation of lift. $C_{L}$ is higher for the whole lift curve

- Total drag reduction

- Improved lift-to-drag ratio. The maximum value increased by up to 15 percent

- Delayed separation of air (wing stall)

- Significantly increased range

- Improved takeoff and landing performance

- Shorter climbing time

- Reduced engine emissions

- Meeting operational constraints for a minimum of added span

- Reduced turbulence behind aircraft and reduced the time gap between the landings

Drawbacks:

- Increased parasite drag due to increased wetted surface

- Increased weight due to the device itself

- Requires new structural study of the wing

Thus, in order to achieve all the above mentioned benefits in the Pareto sense of best trade-off combinations between benefits and drawbacks, shape optimization studies are required for every winglet concept.

\section{REFERENCES}

[1] Faye, R., Laprete, R. and Winter, M.: Blended Winglets, Aero, No. 17,. Boeing, 2002.

[2] Chambers, J. R.: Concept to reality: Constributions of NASA Langley Research Center to U.S. Civil Aircraft of the 1990s (Washington, DC: NASA SP2003-4529,2003.

[3] Langevin, G.S. and Overbey, P.: To reality: Winglets, NASA Langley Research Center, October 17, 2003.

[4] Bargsten, C.J. And Gibson, M.T.: NASA Inovation in Aeronautics: Selected Technologies That Have Shaped Modern Aviation, NASA TM/2011216987, 2011.

[5] Anderson, J.D.: Fundamentals of Aerodynamics, McGraw-Hill Science/Engineering/Math; 5th Ed. 2010.

[6] Saravanan, R.: Design of Parametric Winglets and Wing tip devices - a conceptual design approach, Lincopiln Studies in Science and Technology, Linkping, Sweden, 2012. 
[7] ANSYS Fluent 14.5: User's guide, ANSYS, Inc., Canonsburg, PA, 2013.

[8] Molnar, M: Boeing Says Radical New Winglets on 737 MAX Will Save More Fuel/ NYC Aviation. Retrieved 3 May 2012.

[9] Minnella, G., Rodriguez, Y.J. and Ugas, J. (advisor: George S. Dulikravich): Aerodynamic Shape Design Optimization of Winglets, Senior Design Project, Mechanical and Materials Engineering Dept., Florida International University, Miami, Florida, October 25, 2010.

[10] Guerrero, J.E., Maestro, D. and Bottaro, A.: Biomimetic Spiroid Winglets for Lift and Drag Control, University of Genoa, Italy, Academie des Sciences, Elsevier Masson SAS, 2011.

[11] Azlin, M.A., Mat Taib, C.F., Kasolang, S. and Muhammad, F.H.: CFD Analasys of Winglets at Low Subsonic speed, World Congress on Engineering, London, U.K., 2011.

[12] Versteeg, H.K. and Malalasekera, W.: An introduction to Computational Fluid Dynamics: The Finite Volume Method, Pearson education limited, 1995.

[13] Rasuo, B., Parezanovic, V. and Adzic, M.: On Aircraft Performance Improvement by Using Winglets, University of Belgrade, Serbia, ICAS 2008.

[14] Rasuo, B.: Flight Mechanics, Faculty of Mechanical engineering, University of Belgrade, ebook, 2014.

[15] Gavrilovic, N.,: Improve the Performance of Commercial Aircraft Using Winglets, M.Sc. thesis, University of Belgrade, Faculty of Mechanical Engineering, Belgrade, May, 2014. (in Serbian)

[16] Reddy, S.R., Sobieczky, H., Abdoli, A., Dulikravich, G.S.: Winglets - Multiobjective Optimization of Aerodynamic Shapes, 11th World Congress and 5th European Conference on
Computational Mechanics, 6th European Conference on Computational Fluid Dynamics, Barcelona, Spain, July 20-25, 2014.

\section{ПОБОЉШАҢЕ ПЕРФОРМАНСИ ПУТНИЧКИХ АВИОНА УПОТРЕБОМ ВИНГЛЕТА}

\section{Никола Н. Гавриловић, Бошко П. Рашуо, Ђорђе С. Дуликравић, Владимир Б. Парезановић}

Једно од основних питања које се поставља у путничкој комерцијалној авијацији данас у свету, је питање постизања што економичније цене превоза по превезеном путнику или пређеном километру. У том контексту, у конкурентској борби међу произвођачима и корисницима комерцијалних авиона, сваки допринос је добродошао. Ови доприноси се могу остварити у сфери аеродинамичких, технолошких и експлоатационих унапређења и побољшања. У сфери аеродинамичких унапређења путничких авиона значајно место заузима употреба, развој и оптимизација облика винглета крила.

У раду је посебно проучен утицај примене винглета на перформансе путничких, комерцијалних авиона. Посебну пажња је усмерена ка искуству природних летача у контексту бионичких решења, а и дати су предлози оптимизације облика са становишта највећег долета са постојећом количином горива. У раду је конкретно за изабрани тип путничког, комерцијалног авиона, користећи савремене инжењерске, програмске пакете за аеродинамичко пројектовање и оптимизацију анализиран утицај различитих облика винглета на перформансе лета. Пажња је сконцентрисана на постизање највећег долета. 